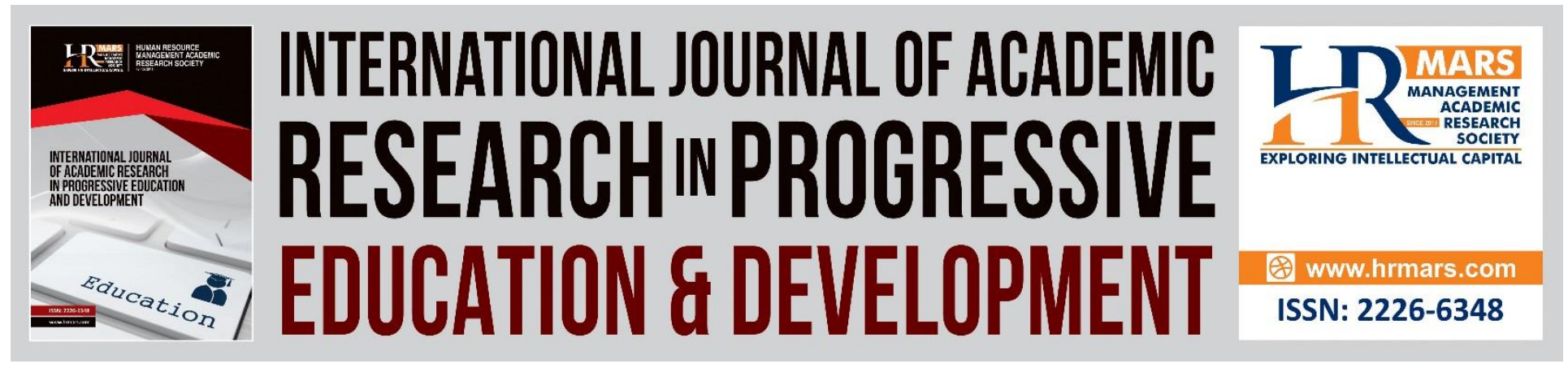

\title{
I-Think Multiple Changes in The Teachers Teaching
}

Roselizam Daud, Roslan Ab Rahman, Nashaat Baioumy, Mustafa Che Omar, Ab Aziz Sulaiman, Wan Ismail Wan Abdullah, Muhammad Hafizi Rozali

To Link this Article: http://dx.doi.org/10.6007/IJARPED/v10-i2/10405 DOI:10.6007/IJARPED/v10-i2/10405

Received: 09 April 2021, Revised: 30 April 2021, Accepted: 24 May 2021

Published Online: 21 June 2021

In-Text Citation: (Daud et al., 2021)

To Cite this Article: Daud, R., Rahman, R. A., Baioumy, N., Omar, M. C., Sulaiman, A. A., Abdullah, W. I. W., \& Rozali, M. H. (2021). I-Think Multiple Changes in The Teachers Teaching. International Journal of Academic Research in Progressive Education and Development, 10(2), 854-866.

Copyright: (C) 2021 The Author(s)

Published by Human Resource Management Academic Research Society (www.hrmars.com)

This article is published under the Creative Commons Attribution (CC BY 4.0) license. Anyone may reproduce, distribute, translate and create derivative works of this article (for both commercial and non-commercial purposes), subject to full attribution to the original publication and authors. The full terms of this license may be seen at: http://creativecommons.org/licences/by/4.0/legalcode

Vol. $10(2)$ 2021, Pg. 854 - 866

http://hrmars.com/index.php/pages/detail/IJARPED JOURNAL HOMEPAGE

Full Terms \& Conditions of access and use can be found at http://hrmars.com/index.php/pages/detail/publication-ethics 


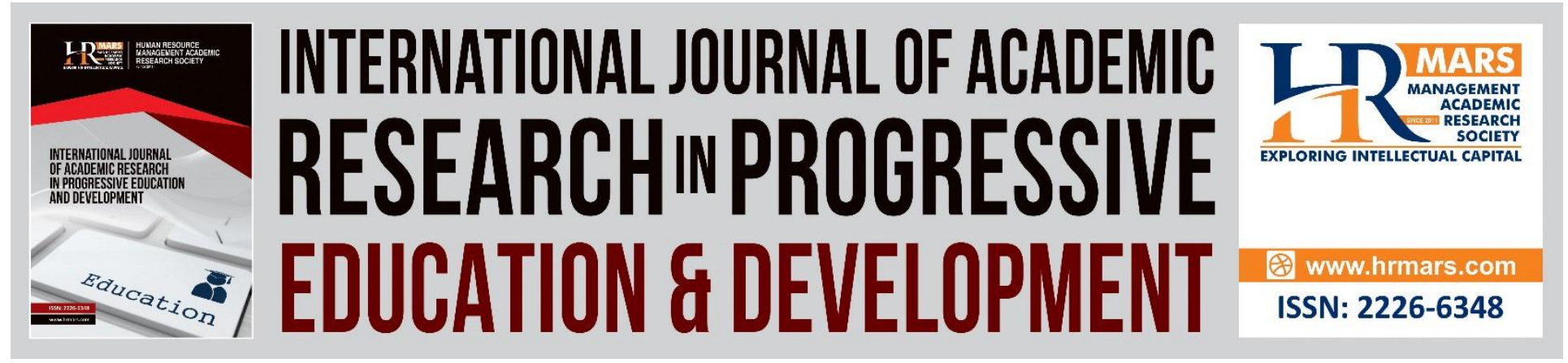

\title{
I-Think Multiple Changes in The Teachers Teaching
}

\author{
Roselizam Daud, Roslan Ab Rahman, Nashaat Baioumy, Mustafa \\ Che Omar, Ab Aziz Sulaiman, Wan Ismail Wan Abdullah, \\ Muhammad Hafizi Rozali
}

Faculty of Islamic Contemporary Studies (FKI), University of Sultan Zainal Abidin (UniSZA), Gong Badak Campus, 21300 Kuala Nerus, Terengganu, Malaysia

Email: roslanabr@unisza.edu.my

\begin{abstract}
This concept paper will discuss issues related to the concept of $i$-Think in the teaching process in schools. The definition of $\mathrm{i}$-Think is explained through the introduction of the thinking tool used, namely, the eight thinking maps for teachers and students in the teaching and learning process and the way they are implemented. In addition, this concept paper also explains the importance and challenges of implementing it in schools. It is intended to expose many stakeholders to the importance of applying i-Think thinking maps to create an effective 21st-century teaching and learning process. According to the Malaysian Education Development Plan (PPPM) 2013-2025, it highlights six key features that every student needs to compete globally to strengthen the existing education system. One of the elements mentioned is improving your thinking skills. Today, the development of correct and comprehensive thinking skills is crucial to become a developed and high-quality country, especially in education. Thinking tools such as the use of visual management have proven their effectiveness in low-performing schools such as the United Kingdom, Canada and the United States. Based on the literature review of the use of graphic management in the teaching practices of teachers in Malaysia such as the mind map is still low and does not encourage students to be more creative and critical in their learning. Therefore, our education system which does not emphasize high level thinking skills should be taken seriously by all parties.
\end{abstract}

Keywords: i-Think Thinking Map, High Level Thinking Skills, Challenges in Teaching i-Think, Teaching Teachers in i-Think, Malaysia Education Plan (PPPM) 2013-2025

\section{Introduction}

The Malaysian Education Development Plan (PPPM) 2013-2025 is a long-term strategic plan that aims to improve the quality of education in the country over the next 13 years with the implementation of a comprehensive education transformation. Five (5) system aspirations and six (6) student aspirations have been identified as catalysts to drive future National educational 
excellence. Among the successes of the implementation of the education transformation is that the Ministry of Education Malaysia (KPM) intends to place the country in the top three in international assessments such as TIMSS and PISA within 15 years of High Level Thinking (ECC) and School Implementation in Education (Ministry of Education, 2017).

To achieve this goal, everyone needs to support and play their role. Teachers in particular need to equip themselves with knowledge and skills as well as new teaching and learning practices relevant to the 21st century's development and needs, thinking skills across all disciplines of students need to be given priority. Teachers and students' thinking skills especially in the context of Higher Thinking Skills (NEP) is an essential element in determining the success of educational transformation as outlined in PPPM 2013-2025. Under the PPPM, teachers are supported in the form of Ongoing Professionalism (PPB), In-Service Training (LDP) and assistance from SISC + to apply ITS in PdP. Sharing in the Professional Learning Community (PLC) is also one of the ways in which teachers can increase their knowledge and skills about EAT, as well as learning self-access. School administrators and parents are also encouraged to assist in implementing ITS through media briefings and Ministry policy interaction sessions Examples of CSR activities are implemented in the classroom (Ministry of Education Malaysia \& MOE, 2015).

Malaysia's achievements in the Trends in Mathematics and Science Study (TIMSS) in 2007 ranked 20th in Mathematics and 21st in Science among 49 countries. Meanwhile, the 2009 Program for International Student Assessment (PISA) reports that Malaysia ranks 57th for Maths, 55th for Science and 52 nd for Understanding among 74 countries. This finding is further reinforced by a report on the need for research by Kestrel Education (UK) and 21 Century Schools (USA) on November 2, 2011, which found that the level of thinking among teachers and students in Malaysia is very low (PADU, 2015).

The Ministry of Education (KPM) began introducing creative and critical thinking skills in the Creative and Critical Thinking Skills (CBC) program in 1994. Teachers have been introduced to various thinking tools. However, the findings of the study have shown that teachers lack high level thinking skills in their teaching and learning. Teaching in the classroom is very teachercentered and leads to preparation of examinations (Zainudin \& Iksan, 2015).

To kick-start the project, the pilot project of the i-Think program was implemented in January 2012. The Ministry of Education Malaysia (KPM) has selected ten primary and secondary schools located in urban and rural areas. Subsequently, the i-Think program was extended to selected schools receiving exposure to the i-Think cohort 1 and cohort 2 programs in 2012 and 2013. The disclosures were made face-to-face in the form of i-Think courses by the Curriculum Development Division, Ministry of Education Malaysia (CPC, KPM) in collaboration with the Malaysian Innovation Agency (AIM) (KPM, 2014).

Today, the i-Think program introduced from 2011 has been running for nearly nine years. The ongoing i-Think program in all schools across Malaysia emphasizes the adoption of teaching and learning approaches by using thinking tools as the main application of this program (Zainudin \& Iksan, 2015). Meanwhile, according to the Curriculum Development Division of the Ministry of 
Education Malaysia, the i-Think Program has introduced a learning approach using eight thinking tools called Thinking Map as well as effective questioning techniques to promote students' thinking skills during the teaching and learning process. This thinking map approach is based on eight cognitive skills that are fundamental to the teaching and learning process (KPM, 2012). In conclusion, the implementation of this i-Think map needs to be taken seriously from various angles. In terms of school implementation, the i-Think map is not a program or a compulsory subject, but it should be incorporated into the teaching and learning process through activities created by teachers. Teachers can also share the mind maps created as one of the teaching aids in teacgung and learning (PdP). However, in implementing this i-Think map, there are challenges that everyone, especially teachers and students, need to be aware of.

\section{Problem Statement}

Starting over the last six decades, the MOE has always strived to improve and upgrade and conduct comprehensive studies of the educational delivery system and teacher training towards effective learning. Even after the 21st century has come close to the second decade, the issue of COC is still being discussed by scholars both at home and abroad. In the context of education in Malaysia, the MOE has allocated a significant amount of funds for the use of information and communication technology in Malaysian schools. Examples include investments in Smart Schools, the My School Net project, school access centers, Ed Furniture and 1BestariNet to provide schoolchildren with the necessary and essential communication skills of the 21st century (Zaidi et al., 2015).

In fact, through the 2020 Budget the government has also allocated RM64.1 billion of the country's total budget allocation this year, reflecting the government's commitment to national education. Expenditure on maintenance and upgrading of schools increased from RM652 million in 2019 to RM735 million in 2020. (KPM, 2020). This demonstrates the government's high commitment to developing a 21st century skilled student population as outlined in the Malaysian Education Development Plan 2013-2025 (Ministry of Finance Malaysia \& Finance Malaysia, 2018).

Many new discoveries and inventions have been made by humans that have had a profound impact on the quality of human life around the world. Among the notable developments is the expansion of the use of automation, robotics and Internet of Things (IoT) technologies that are expanding industries in new forms such as online, big data, robotics, network security and reality industries. virtual reality (Abdullah, 2020). The i-Think mapping also needs to be used by teachers in PdPc to ensure that PAK-21 can be implemented.

In the last five years, studies related to the use of maps thinking i-Think in schools in Malaysia has almost covers all the subjects studied in the subjects of English (Yusof \& Mahamod, 2015; Aloysius \& Othman , 2017; Jamian, 2017; Ahamad, Amzah, \& Yaakub, 2016), Mathematics (Zaidi, Rosli, \& Nor, 2015b; Zaidi et al., 2015b), Science (Mansor, Nashirah, Abdullah, \& Yussuf, 2015; Zainudin \& Iksan, 2015; Murad \& Abdullah, 2016), Economics (Lee 2015), History (Tamdjis 2017). on the exposure of i-Think programs at school level to the holistic approach of schools (Sa'ban \& 
Ghani and Darusalam, 2015), as well as studies on application of mind maps i-Think in enhancing high-level thinking skills (END) studied by (Zakaria \& Ali, 2018). However, studies on the influence of acceptance and use of $\mathrm{i}$-Think mapping among teachers have been lacking.

The Malaysian Education Development Plan 2013-2025 aims to produce students who are capable of mastering high-level thinking skills (EAT) including critical thinking, reasoning, creative thinking, and innovation. However, students' achievement in this area did not reach satisfactory levels, the results showed that some students could not apply the knowledge they had learned in the classroom using EAT to the context outside the classroom. Studies show that teachers are one of the main factors that influence success or failure in teaching for EFFECT. As a result, KPM has implemented an i-Think program to assist teachers with KNOW knowledge and skills.

All of these findings have prompted the ministry to further strengthen its efforts towards generating creative and innovative human capital. This effort is to meet the challenges of the 21st century that requires the capability of thinking at a high level. However, the problem is that the school system has less emphasis on the task of developing student thinking. The focus is only on the preparation of information with the aim of preparing students for the examination and completing the syllabus. There are several reasons why thinking skills are not emphasized, as some teachers simply assume that students first master all the facts and concepts of a subject before they can be encouraged to think (Joseph \& Mahamod 2015).

\section{Literature Review}

\section{Definition of i-Think Map}

Thinking maps are a visual tool presented in eight form of visual maps that are easy to use and understand across the curriculum. According to the Curriculum Development Division, the mind map incorporates cognitive learning processes and visual presentation of information in graphic form. A mind map can also be used to define something in a context that is appropriate, can be explained using adjectives / phrases, can be compared, can be classifed, can be part of, can be, order and cause, can be analogous to something and can be a visual thought that is common to the classroom and school.

\section{Concept Map of i-Think}

Each mind map has its own thought process. The use of this map can also be customized by title or lesson unit based on an illustration of an existing mind map (KPM 2014). Mind maps resemble other thinking tools such as mind maps and concept maps, however, thinking maps are more organized, structured and well-designed. The mind map has eight types or shapes and each type has its own function to describe something.

\section{Features of the i-Think Map}

The development of cybersecurity and access to the internet demands changes in teaching and learning methods. The field of education needs to be enhanced in shaping 21st century students. Characteristics of the 21st century students are capable of connecting, intelligently interrogating, confident in communicating, thirst for knowledge, taking risks, curious, generating ideas, being flexible, giving up, listening and reflecting, critical thinking, mastering literacy skills, Dare to try, 
be self-aware, innovative, able to work with people, make changes, be honest and have high personalities (Shift Bulletin No.4 / 2015).

Implementation of the Primary School Curriculum (KSSR) from 2011 and the Secondary School Curriculum (KSSM) from 2017 is an educational transformation in an effort to create a balanced human capital that can meet current and future challenges (Sharifah Nor 2012). In line with this, the KPM has teamed up with the Malaysian Innovation Agency (under the Prime Minister's Department) to implement the i-Think Program by introducing i-Think thinking maps as a thought-provoking tool that can stimulate student thinking and potentially enhance students' level of learning (Vishalache et al., 2014).

Here are there eight types of $\mathrm{i}$-Think thinking maps used in teacher teaching and learning. Mind Map or i-Think Map is one of the elements of High Level Thinking Skills (END). I-Think Maps are highly recommended for application in learning and programming activities (PdPc). Generally speaking, this mind map has eight types:

1. Circle Map

2. Bubble Map

3. Double Bubble Map

4. Tree Map

5. Capture Map

6. Flow Map

7. Multi-Flow Map

8. Bridge Map

There have been numerous studies that have studied the use of $\mathrm{i}$-Think mapping in schools (Yunas \& Mahamod 2017); (Layang et al. 2019); (Zamri et al., 2019); (Othman et al., 2014); (Othman et al., 2014); (Jamian, 2017); (Mingan \& Mahamod, 2016); (Linsah \& Mahamod, 2018); (Joseph \& Mahamod, 2015); (Fatah, 2015). However, these studies point to specific areas in the effectiveness of using i-Think thinking maps in improving student achievement and high level thinking skills. Omar's (2018) study found that teachers' thinking methodology in teaching and facilitating $(\mathrm{PdPc})$ in a smart classroom can be classified into three sections, namely the principle of thinking (Thinking Language and Thinking Behavior); ways of thinking (Thinking, Spiritual and Thinking); and thinking tools. This methodology thinks that it is a self-fulfilling ability that is beyond the reach of others because it requires less effort. In fact, this thinking methodology is a catalyst mechanism in PdPc CELL. Therefore, a teacher needs to think outside the context of a habit, looking at things from a variety of fields and expertise.

Therefore, previous research has reported that teachers' approach to student learning is considered the right solution to address the problem. Fadhil and Yamat (2019) found that students do not plan before beginning to writite in their learning and thus have no idea how to construct a sentence. Teachers should take it seriously because it can create an effective and fun learning environment by guiding students using i-Think thinking maps. Therefore, this study will 
Vol. 10, No. 2, 2021, E-ISSN: $2226-6348$ @ 2021 HRMARS

identify the effects and challenges of using i-Think thinking maps in teaching and learning in schools so as to stimulate students' thinking to a higher level of thinking.

Based on recent research highlights that the level of usage of i-Think maps still needs to be improved. For example, the level of readiness for using thinking maps is at a moderate level, where more than $60 \%$ of teachers practice thinking skills. Teachers were found to still apply the use of $\mathrm{i}$-think maps in the teaching and learning (PdP) process to enhance student learning knowledge even though the teacher practice level is at a moderate level (Layang \& Mahamod, 2019), (Hasan \& Mahamod, 2016). This is because the level of knowledge and the level of teachers' attitude towards using i-think maps is high. Teachers must master the level of practice of the method because they play a role in educating an individual to be better and to evaluate students. The use of graphical and visual materials can stimulate thinking, enhance memory and facilitate student understanding (Hasan \& Mahamod, 2016).

\section{Research Objective}

The objectives of this study is to:

Explain the importance and challenges of i-Think thinking maps in teacher teaching.

\section{Methodology}

This study uses a qualitative approach in the form of a library study. The literature is focused on academic materials on the challenges of i-Think mapping in teacher teaching.

\section{I-Think Multiple Changes in The Teacher's Teaching}

Implementation of the i-Think map needs to be taken seriously from various angles. In terms of school implementation, the i-Think map is not a program or a compulsory subject matter, but it should be incorporated into the teaching and learning process through teacher-created activities. Teachers can also share a mind map they created as one of the teaching aids in PdP. However, in implementing this i-Think map, there are challenges that everyone, especially teachers and students, need to be aware of, the education system in Malaysia is now the system that makes examinations the basis of student assessment by emphasizing on memorizing and re-examining facts. Recognizing the importance of High Level Thinking Skills emphasized in the analysis of PISA and TIMSS and the Malaysian Education Development Plan (2013-2025), i-Think thinking maps were introduced in all primary and secondary schools. Although these thinking tools help students to seek knowledge, initiatives need to be made and they also need to develop those skills in order for them to succeed in an ever-changing world.

One of the issues that is considered obsolete but still practiced is that chalk and talk teaching methods are no longer relevant to the 21st century learning style. The features of 21st century learning include communication, critical thinking, collaboration and creativity. However, educators still practice more teacher-centered teaching and learning methods and practice conventional methods of teaching (Revised Bulletin No.4 / 2015). Conventional teaching methods show that teachers dominate the classroom (Fauziah et al., 2005). 
Conventional methods such as chalk and talk methods simply do not succeed in attracting students, but require more dynamic and creative methods (Shift Bulletin, No. 4/2015). In line with the 21st-century learning-based approach to teaching, teachers are only responsible for providing stimulating learning materials. Students study in groups or use learning aids including a variety of reading materials, audio, video, computers and the internet (Language Learners, 2016). Therefore, the use of i-Think mapping as a 21st century thinking tool is appropriate for teachers to transform teacher-centered teaching methods to students while also stimulating and enhancing high-level thinking skills.

The transformation of the educational curriculum in PPPM 2013-2025 also emphasizes the concept of CULT that is capable of producing a generation of critical and creative thinkers. Through PPPM 2013-2025, every student is targeted to develop thinking skills, leadership skills, bilingual skills, knowledge, ethics and spirituality and national identity. In line with the National Philosophy of Education, thinking skills are one of the six key features that every student needs to compete globally (Malaysian Education Development Plan, 2013-2025, MOE 2013).

The transformation of the country's education through the implementation of the Primary School Curriculum (KSSR) introduced in 2011 and the introduction of the Secondary School Curriculum (KSSM) in 2017, among others, to produce critical, creative and innovative students (Nor 2012). The teaching and learning ( $\mathrm{PdP})$ process will be based on skills and thinking strategies that require the use of planned PdP methods in order to develop students' mindsets based on the new curriculum standards introduced by the MOE. The production of new ideas among teachers by incorporating the elements of CYD can enhance the effectiveness of the PdP process in the classroom.

Further study by Yusop \& Mahamod, (2015) found that the school system did not emphasize the task of developing students' thinking skills. The focus is only on the preparation of information with the aim of preparing students for the examination and completing the syllabus. There are several reasons why thinking skills are not emphasized, as some teachers simply think that students should first master all the facts and concepts of a subject before they can be encouraged to think.

Subsequent study of Fadhil and Yamat (2019) found that students do not plan before beginning to write in their learning so that they have no idea how to construct a sentence. Teachers should take it seriously because an effective and fun learning environment can be created by guiding students using i-Think thinking maps.

Similarly, a study conducted by Othman (2017); Layang \& Mahamod (2019), found that teachercentered learning has made students passive. Passive student behavior can be overcomed by activating teacher-student interaction, pupil-to-pupil use and teaching tools while also providing some freedom to think creatively through active engagement and facilitating students' ideas. 
The need to complete the syllabus is also a problem that teachers face in terms of time constraints. Problems with passive and silent learners also impede the implementation of the iThink program. Various programs and exposures should be given to teachers so that they can implement the i-Think program more effectively Vadivalu \& Kamisah, (2015). This finding is supported by the study of Othman, (2017) who stated that the limited time frame and the content of this study were due to Islamic Education subjects being synonymous with the need to spend syllabus for examination.

Emphasis on examinations causes teachers to overlook aspects of their students' thinking skills by focusing on the effort to complete the syllabus and mastering the techniques of answering the questions alone. This can also be seen through a study conducted by (Zamri, 2011), stating that in the context of PdP inquiry is capable of and promotes effective teacher-student interaction. The PdP that is exam oriented has undermined efforts to produce students intellectually, spiritually, emotionally and physically balanced as embodied in the National Philosophy of Education (Ministry of Education Malaysia, 2017).

Recent research highlights that the level of usage of $i$-Think maps still needs to be improved. For example, the level of readiness for using i-think maps is at a moderate level, where more than $60 \%$ of teachers practice thinking skills. Teachers were found to still apply the use of $i$-think maps in the teaching and learning (PdP) process to enhance student learning knowledge even though the teacher practice level is at a moderate level (Kayang \& Mahamod, 2019). The use of graphic and visual materials can also stimulate thinking, enhance memory and facilitate student understanding (Hassan \& Mahamod, 2016). Therefore, previous research has reported that teachers' approach to student learning is considered the right solution to address the problem (Othman, 2017).

According to a study by Mariam et al (2017) related to the knowledge and skills of primary school teachers towards the development of Higher Thinking Skills (Kbat) in learning shows that teachers have a high level of knowledge of CUT practice but have high levels of skills in implementation VERY simple. The findings of this study provide information to the Ministry of Education Malaysia (MOE) in particular to plan and devise strategies for improving ECE among teachers.

In addition, the findings of this study also provide information to school administrators and teachers, especially primary school science teachers. This is because lower education science education is a catalyst to increased student interest in science. At the same time, teachers should strive to improve their high-level thinking skills as well as their students.

The use of i-Think thinking maps can be customized by title or unit of study based on related subtopics (David \& Rahman, 2020). The use of different forms of i-Think mapping can encourage students to have creative, critical and innovative thinking. In addition, it also creates a fun learning environment. In the context of learning, the application of i-Think thinking maps is an approach that enables students to solve problems. In addition, students can engage in an active 
learning environment. This kind of learning pattern is a form of cooperative learning. According to the study of Yusop \& Mahamod (2015), the use of mind map techniques in essay writing has succeeded in increasing subjectivity in the aspects of essay preparation. (Mansor et al., 2015), also stated that the implications of his study enabled students to understand i-Think thinking maps more clearly and indirectly to engaging students in learning and improving their achievement. Hence, the use of mind maps as a way of stimulating high school thinking. The study of Tamdjis (2017) also found that overall student interest was at a high level. The i-Think map is vital in enhancing the pedagogical capabilities of teachers in diversifying 21st century teachers' skills in line with current technological developments and the new information.

\section{Conclusion}

In conclusion, this change of learning through the application of $i$-Think mapping must be made and implemented as much as possible to create 21 st century student-centered learning as a facilitator despite the challenges in its implementation. The application of the i-Think map must be emphasized to produce creative, critical in thinking. The use of this i-Think technique enables teachers to take the opportunity to implement collaborative learning in the classroom. This method is used to enable pupils and teachers to interact with each other during the teaching and learning process.

As such, this will create a teamwork relationship among students while strengthening and enhancing communication skills among students. In the context of learning, the application of iThink mapping techniques in teaching and learning can be categorized as an approach or facilitator for students to solve problems or make connections between given topics. In addition, students are also involved in an active learning environment and can improve communication skills between students. This kind of learning pattern is a form of cooperative learning. However, a more comprehensive study of the use of i-Think maps in enhancing the thinking culture among teachers and students should be undertaken.

\section{Corresponding Author}

Roslan Ab Rahman

Centre for Education, Dakwah and Islamic Civilization Studies, Faculty of Islamic Contemporary Studies (FKI), University of Sultan Zainal Abidin (UniSZA), Gong Badak Campus, 21300 Kuala Nerus, Terengganu, Malaysia.

Email: roslanabr@unisza.edu.my

\section{References}

Abdullah, A. H. (2020). Islamic Education In an Era of the Industrial Revolution 4.0. TAMADDUN. doi: 10.30587 / tamaddun.v21i1.1384, Malaysia.

Jamian, A. R. (2017). Use of i-Think Thinking Maps in Understanding KOMSAS Malay. Malaysian Journal of Education..

Jamian, A. R., Misdon, M., \& Sabil, A. M. (2017). Use map l-Think thoughts in Understanding KOMSAS Malay. Malaysian Journal of Education 42 (1): 51-59. doi: 10.17576 / JPEN-2017-\% x. Malaysia. 
Ahamad, A., Amzah, F., \& Jacob, R.. (2016). Application of Circular Maps and Flow Maps in the process of Creating Poems. International Conference on Education and Psychology 2016 (ICEduPsy16). Malaysia.

Murad, A., \& Abdullah, N. (2016). Development of the I-think map module for science subjects in elementary school. Journal of Science \& Mathematics Education Malaysia 6 (2). Malaysia.

Christine, L., \& Mahamod, Z. (2018). The level of knowledge, acceptance and control Bukar Bidayuh ethnic students in learning Malay language dung through map-thinking $i$ think. International Journal of the Malay World and Civilization (International Journal of Malay World and Civilization). Malaysia.

Fadhil, F., \& Yamat, H. (2019). I-Think Map in the Organization of Ideas in Argumentative Writing. International Journal of Academic Research in Business and Social Sciences 10 (1): 1-13. doi: 10.6007 / IJARBSS / v10-i1 / 6808. Malaysia.

Layang, F., \& Mahamod, Z. (2019). The level of knowledge, willingness and attitude of Malay Primary School Teachers in Implementing Teaching and Learning Map i-Think thoughts. (Malay). Knowledge, Readiness and Attitude of Malay Language Primary School Teachers in Kapit district to Implementing i-Think Map in Teaching and Learning. (English). doi: 10.17576 / jpen-2019-44.01-05. Malaysia.

Fatah, N. A. A. Z. (2015). Knowledge Levels of i-Think Maps in Student Circuits. 6th Pedagogy International Seminar 2015. Malaysia.

Mingan, J., \& Mahamod, Z. (2016). Knowledge of High School Students Thinking About Using Maps in Learning English. Malay Language Education 6 (2): 23-32. Retrieved fromttp://p library2.upsi.edu.my/eprints/2418/1/. Malaysia.

Ministry of Finance Malaysia \& Finance Malaysia, K. (2018). Budget 2019. Ministry of Finance Malaysia. doi: 10.1017 / CBO9781107415324.004. Malaysia.

Malaysia Education Ministry. (2013). The i-Think Program. Malaysia Education Ministry. Putrajaya, Malaysia.

Malaysia Education Ministry. (2017). PPPM Executive Summary 2013-2025. KPM. doi: 10.1017 / CBO9781107415324.004. Putrajaya.

Othman, K., Ismail, S., Jaafar, H. \& Samsudin, A. (2014). Case study: application of i-Think Maps in number literacy teaching and learning. Journal of RESEARCH Research 31: 147-152. Malaysia.

KPM. (2012). Cultivating Thinking Skills. Books. Putrajaya, Malaysia.

KPM. (2014). FUN Elements in Pedagogy. KPM. doi: 10.1007 / s13398-014-0173-7.2, Putrajaya, Malaysia.

KPM, Ministry of Education Malaysia \& KPM. (2015). High Level Thinking Skills (ECCs) and Efficiency Exercises in Schools. Shift Newsletter. Putrajaya, Malaysia.

Lee, Y. H. M. B. H. (2015). Implementation of High Level Thinking Skills through the Use of iThinking Maps in Economics Teaching and Learning. Proceedings of the 5th National National Education Seminar, Malaysia.

Tamdjis, M. F. A. A. (2017). Application of I-Think Maps to Student Achievements and Interests in Historical Education. International Conference on Global Education V. Malaysia. 
Nurhafizah, Z., Roslinda, R., \& Nor, M. Y. (2015). Application of i-THINK Mind Map in the Teaching and Learning Process of Math. World Academic And Research Congress (2015). doi: 10.1016 / j.jbiomech.2012.08.025. Malaysia.

Omar, M. C. (2018). Thinking and Learning Methods (Pdpc) Higher Level Thinking (Kbat) Methods. 321 | MEDC 2018 Proceedings of the National Seminar on the Dean of the Universities Education Council 2018 Editors: Rahimah Embong, Hanif Md Lateh @ Junid, Mustafa Che Omar, Mohamad Zaidin Mohamad \& Abdul Hakim Abdullah elSBN 978-967-2231-03-5 (2018), http: / /www.unisza. Malaysia.

Othman, Y. (2017). Thought to Improve Effectiveness Map Essay Writing Skills Among Malay Students 6. Levels of Education Journal Malay - JBPM 7 (1): 2180-4842. Retrieved from http://journalarticle.ukm.my/10412/1/131-252-1-SM.pdf. Malaysia.

PADU. (2015). March (2015) Bulletin: Higher Level Thinking Skills (EAT) and School Implementation in Schools. Malaysian Education Transformation Bulletin - PPPM 2013-2025. Malaysia.

Joseph, R., \& Mahamod, Z. (2015). Effectiveness of Thinking Maps (i-Think) in Improving Student Achievement in Writing English 6. Malay Language Education Journal - MyLEJ. Malaysia.

Daud, R., \& Rahman, R. A. (2020). Effectiveness of i-Think Maps in Improving Higher Thinking Skills (END). International Social Science and Humanities Journal, 3 (1). doi: e-issn: 2637-0271. Malaysia.

Seman, S. C., Yusoff, W. M. W., \& Embong, R. (2017). Teachers Challenges in Teaching and Learning for Higher Order Thinking Skills (HOTS) in Primary School. International Journal of Asian Social Science. doi: 10.18488 / journal.1.2017.77.534.545. Malaysia.

Sa'ban, S., Ghani, M. F. A., \& Darusalam, G. (2015). Exposure to the i-Think Program at the SchoolBased Approach to the Whole School Approach: A Preliminary Study. Journal of Educational Leadership 3 (1): 32-46. Malaysia.

Embong, A. H., Khairuldin, W. M. K. F. W., Yasin, M. F. M., Hassan, A., \& Ibrahim, M. S. (2021). Between Reformist and Interpretation: Notes on Hamka's Methodological Strategies as Reformist Mufassir. In First International Conference on Science, Technology, Engineering and Industrial Revolution (ICSTEIR 2020) (pp. 415-422). Atlantis Press.

Majid, S. F., Khairuldin, W., \& Ajmain, M. T. (2019). Figh Boycott On LGBT Community: A Review. Perdana: International Journal of Academic Research, 6(2), 35-49.

Anas, W. N. I. W. N., Daud, N., Khairul, W. M., \& Khairuldin, F. W. (2017). The Stance of Alimony or Maintenance for Working Wives within Working Period: An Analysis from the Qualified Jurists (Muftis). International Journal of Academic Research in Business and Social Sciences, 7(4), 2222-6990.

Hassan, S. A., \& Khairuldin, W. (2020). Research Design Based on Fatwa Making Process: An Exploratory Study. International Journal of Higher Education 9 (6), 241-246

Mariam, Z., \& Kamisah, O. (2017). Primary school teachers' knowledge and skills of incorporating High Level Thinking (Kbat) skills into learning. Social Science Postgraduate International Seminar (SSPIS) 2017 619-624. Malaysia.

Zainudin, S., \& Iksan, Z. (2015). Empowerment of High Level Thinking Skills in Science. 5th National National Education Seminar, p. 206-211. Malaysia. 
Vadivalu, V. (2015). Perceptions and problems faced by Science teachers in implementing High Level Thinking Skills. Proceeding 7th International Seminar on Regional Education 2 (0): 10771082. Malaysia.

Zamri, A., \& Hadi. (2019). The Effectiveness of Using I-Think Thinking Map in Enhancing the Mastery of Malay Language Essay Writing Skills of Form 6 in Mukah District The Effectiveness of Using I-Think Thinking Map in Enhancing the Mastery of Malay Language Essay Writing Skills of 8 (4 ): 386-401. doi: 10.6007 / IJARPED / v8-i4 / 6543. Malaysia.

Zamri, M. (2011). Empowering teachers, people better students: teaching and learning of Malay language in the 21st century. Seminar Malay 1-30. Malaysia. 